\title{
Process and mechanism of mountain-root removal of the Dabie Orogen-Constraints from geochronology and geochemistry of post-collisional igneous rocks
}

\author{
LI ShuGuang $^{1,2^{*}}$, HE YongSheng ${ }^{1} \&$ WANG ShuiJiong ${ }^{1}$ \\ ${ }^{1}$ State Key Laboratory of Geological Processes and Mineral Resources, China University of Geosciences, Beijing 100083, China; \\ ${ }^{2}$ CAS Key Laboratory of Crust - Mantle Materials and Environments, School of Earth and Space Sciences, University of Science \\ and Technology of China, Hefei 230026, China
}

Received May 23, 2013; accepted July 15, 2013; published online August 26, 2013

\begin{abstract}
Systematical studies of post-collisional igneous rocks in the Dabie orogen suggest that the thickened mafic lower crust of the orogen was partially melted to form low- $\mathrm{Mg}^{\#}$ adakitic rocks at 143-131 Ma. Delamination and foundering of the thickened mafic lower crust occurred at $130 \mathrm{Ma}$, which caused the mantle upwelling and following mafic and granitic magmatic intrusions. Migmatite in the North Dabie zone, coeval with the formation of low- $\mathrm{Mg}^{\#}$ adakitic intrusions in the Dabie orogen, was formed by partial melting of exhumed ultrahigh-pressure metamorphic rocks at middle crustal level. This paper argues that the partial melting of thickened lower and middle crust before mountain-root collapse needs lithospheric thinning. Based on the geothermal gradient of $6.6^{\circ} \mathrm{C} / \mathrm{km}$ for lithospheric mantle and initial partial melting temperature of $\sim 1000^{\circ} \mathrm{C}$ for the lower mafic crust, it can be estimated that the thickness of lithospheric mantle beneath thickened lower crust has been thinned to $<45 \mathrm{~km}$ when the thickened lower crust was melting. Thus, a two-stage model for mountain-root removal is proposed. First, the lithospheric mantle keel was partially removal by mantle convection at $145 \mathrm{Ma}$. Loss of the lower lithosphere would increase heat flow into the base of the crust and would cause middle-lower crustal melting. Second, partial melting of the thickened lower crust has weakened the lower crust and increased its gravity instability, thus triggering delamination and foundering of the thickened mafic lower crust or mountain-root collapse. Therefore, convective removal and delamination of the thickened lower crust as two mechanisms of lithospheric thinning are related to causality.
\end{abstract}

post-collisional magmatism, mountain root removal, lithospheric thinning, adakitic rocks, migmatite

Citation: $\quad$ Li S G, He Y S, Wang S J. Process and mechanism of mountain-root removal of the Dabie Orogen—Constraints from geochronology and geochemistry of post-collisional igneous rocks. Chin Sci Bull, 2013, 58: 4411-4417, doi: 10.1007/s11434-013-6065-y

Mountain-root removal in collisional zones is an important geodynamic process that can cause mantle upwelling, postcollisional magmatism, and mineralization. Foundering of mafic thickened lower continental crust (LCC) during mountain root removal process plays an important role in the crustal evolution and recycling.

Two models have been proposed for the process and mechanism of mountain-root removal in collisional zones: (1) delamination and foundering of the thickened LCC [1], and (2) the convective removal of mantle lithosphere keel

*Corresponding author (email: 1sg@ustc.edu.cn)
[2]. The first one can explain the relevant intense magmatism, coupled with recycling of lower continental crustal materials in orogenic belt. It is, however, very difficult to imagine that the limited negative buoyancy produced by eclogitic LCC no more than $30 \mathrm{~km}$ thick together with $100-150 \mathrm{~km}$ thick mantle lithosphere with a low density can cause the break and delamination of the dry LCC rocks. The second one can easily explain the removal of the lithospheric mantle root, but requires the thinning of the thickened crust following the removal of lithospheric keel. No partial melting and recycling of thickened LCC, thus, would be expected. 
The Dabie orogen provides the best case to study this issue. The ultrahigh-pressure metamorphic (UHPM) rocks in this orogen demonstrate that the continental crust has been subducted to $>100 \mathrm{~km}$ depth during the continental collision. However, current crustal depth of the Dabie orogen is $35-40 \mathrm{~km}$ without a thickened mountain root underneath, suggesting that mountain root of the Dabie orogen has been removed by a certain geological event. The Dabie orogen is a cold collisional orogen. No magmatism had occurred from the early Triassic, the beginning age of continental collision between the North China and South China Blocks, to the early Cretaceous. This suggests the preservation of mountain root during this period. Intensive early Cretaceous magmatism related to the mountain root removal in the Dabie orogen provides good conditions to study the process and mechanism.

\section{Geochemistry of post-collisional granites in the Dabie orogen}

\subsection{Identification of partial melts from thickened LCC}

Geochrologically, Dabie post-collisional granites can be divided into two groups: early granites (143-131 Ma) and late granites (131-117 Ma). Previous studies have found that the early granites in the Dabie orogen have high $\mathrm{Sr} / \mathrm{Y}$ and $\mathrm{La} / \mathrm{Yb}$ features whereas the later ones do not have, suggesting the early granites as adakitic rocks [3-6]. High $\mathrm{Sr} / \mathrm{Y}$ and $\mathrm{La} / \mathrm{Yb}$ features, however, can also be found in normal granites with other petrogenesis [7-16], and thus do not convincingly indicate that the early granites are partial melts of thickened LCC. He et al. [17] found that Dabie early high $\mathrm{Sr} / \mathrm{Y}$ granites define special trends in $\mathrm{Sr}-\mathrm{SiO}_{2}$ and $\mathrm{Sr}-\mathrm{CaO}$ patterns with higher $\mathrm{Sr}$ contents compared to the late normal granites, and have positively correlated, variably with high $(\mathrm{La} / \mathrm{Yb})_{\mathrm{N}}, \mathrm{Sr} / \mathrm{Y},(\mathrm{Dy} / \mathrm{Yb})_{\mathrm{N}}$ and $\mathrm{Nb} / \mathrm{Ta}$ (Figure 1). These features can only be explained by crustal partial melting leaving a residue that contains much garnet, trace rutile, but no plagioclase, indicating crustal depth $>50$ $\mathrm{km}$. This suggests that thickened mafic LCC was still present at 143-131 Ma, and partially melted to produce low- $\mathrm{Mg}^{\#}$ adakitic rocks [17]. The new criteria propsed by $\mathrm{He}$ et al. [17] could be used to identify low-Mg $\mathrm{Mg}^{\#}$ adakitic rocks from those with high $\mathrm{Sr} / \mathrm{Y}$ fearture but non-high pressure origin ones, and implication for the literature data suggests that such non-high pressure high $\mathrm{Sr} / \mathrm{Y}$ granites can be efficiently identified .

\subsection{Constraints on the timing of mountain-root removal}

High $(\mathrm{La} / \mathrm{Yb})_{\mathrm{N}}, \mathrm{Sr} / \mathrm{Y},(\mathrm{Dy} / \mathrm{Yb})_{\mathrm{N}}$ and $\mathrm{Sr} / \mathrm{Ca}$ features, indicating partial melting of thickened LCC, disappeared in the Dabie post-collisional granites after $130 \mathrm{Ma}$ (Figure 2). This suggests that the thickened LCC has disappeared beneath the Dabie orogen since $130 \mathrm{Ma}$, and the later granites were produced by partial melting of lower-middle crust in normal depths leaving a plagioclase-rich residue. This transition era is consistent with the emplacement age of mantle-derived mafic intrusions at 131-123 Ma (Figure 2 ), reflecting the mantle upwelling as a response to foundering of the thickened LCC [6,18-22]. In addition, the post-collisional mafic intrusions in the Dabie orogen have $\mathrm{Sr}-\mathrm{Nd}$ isotopes similar to low- $\mathrm{Mg}^{\#}$ adakitic rocks, which also indicates an upwelling mantle hybridized by the foundered LCC [18]. Therefore, mountain root of the Dabie orogen collapsed at ca. $130 \mathrm{Ma}$ [17].

Mountain-root removal and foundering of thickened mafic LCC not only caused mantle upwelling and mafic magmatism, but also induced partial melting of lowermiddle crust of the orogen, producing the large volume of granitc magmas after $130 \mathrm{Ma}[4,5,17,23]$. Although ore resources are scarce in the central Dabie zone where nowadays middle-lower crust is exposed due to uplifting and erosion by magma doming [24-26], the Cretaceous giant Mo deposit discovered in the North Dabie zone and the North Huaiyang zone indicates that the mountain root removal process may help mineralization [26]. Partial melting of thickened LCC that occurred prior to the mountain root removal must have weakened the LCC and increased the gravity instability, which could be an important trigger to detach the thickened LCC from the upper crust. In contrast, there was no magmatism before $143 \mathrm{Ma}$ in the Dabie orogen, when eclogitic mafic LCC could not be detached and foundered due to its high strength despite the gravity instability.

\section{Geochemistry of Dabie migmatites: evidence for partial melting of exhumed UHPM slices at middle crust}

Previous studies suggest two stages of migmatization in the North Dabie zone. The white and deformed leucosome occurs as the early stage with an age of ca. $139 \mathrm{Ma}$, whereas the light pink dikes occur at ca. $123 \mathrm{Ma}$ as the late stage without deformation [27]. Since the early stage migmatites have the same formation age as the low- $\mathrm{Mg}^{\#}$ adakitic rocks, we focus on the question whether or not the leucosomes have the same geochemical features and sources with the low-Mg $\mathrm{Mg}^{\#}$ adakitic rocks. Below, we briefly introduced the geochemistry and formation conditions of the early stage leucosome, which have been studied by Wang et al. [15].

\subsection{Geochemical classification of the leucosome}

Leucosome of the early stage migmatite can be divided into three groups according to their geochemical features: (1) high $(\mathrm{La} / \mathrm{Yb})_{\mathrm{N}}$, medium Sr/Y group; (2) low $(\mathrm{La} / \mathrm{Yb})_{\mathrm{N}}, \mathrm{Sr} / \mathrm{Y}$ group; and (3) high $(\mathrm{La} / \mathrm{Yb})_{\mathrm{N}}$, high $\mathrm{Sr} / \mathrm{Y}$ group with strong 

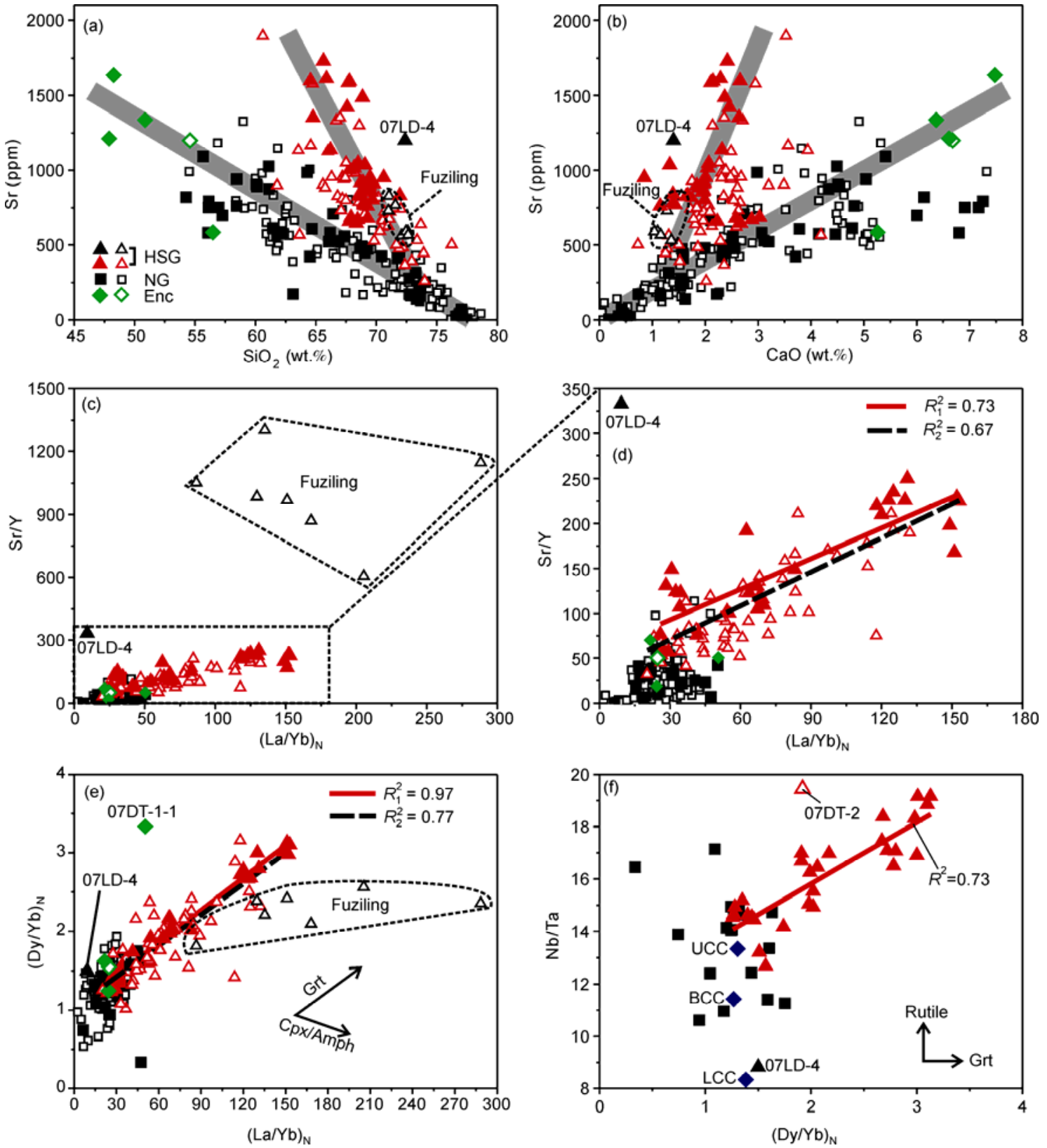

Figure 1 (a) and (b) Dabie low-Mg\# adakitic rocks (HSG) and normal granites (NG) define two separate trends with high Sr and low Sr contents respectively in the $\mathrm{Sr}_{-} \mathrm{SiO}_{2}$ and $\mathrm{Sr}-\mathrm{CaO}$ patterns [17]. Enc represents the mafic enclaves in the granites. (c)-(f) $\mathrm{Sr} / \mathrm{Y},(\mathrm{Dy} / \mathrm{Yb})_{\mathrm{N}}$ and $(\mathrm{La} / \mathrm{Yb})_{\mathrm{N}}$, as well as Nb/Ta and $(\mathrm{Dy} / \mathrm{Yb})_{\mathrm{N}}$ are positive correlated for low-Mg adakitic rocks. UCC, LCC, and BCC represent the upper, lower and bulk continental crust, respectively. Explaination of few outliers (e.g., Fuziling, 07LD-4, 07DT-1-1, 07DT-2) is referred to [17].

positive Eu anomaly. Groups (1) and (3) are plotted in the adakite field in the $(\mathrm{La} / \mathrm{Yb})_{\mathrm{N}^{-}} \mathrm{Yb}_{\mathrm{N}}$ and $\mathrm{Sr} / \mathrm{Y}-\mathrm{Y}$ diagrams, but both are non-high pressure origin. Group (3) has lower $(\mathrm{Dy} / \mathrm{Yb})_{\mathrm{N}}$ and higher $\mathrm{Sr} / \mathrm{Y}$ than low-Mg $\mathrm{Mg}^{\#}$ adakitic rocks at a given $(\mathrm{La} / \mathrm{Yb})_{\mathrm{N}}$. Given the strong positive $\mathrm{Eu}$ anomaly and the fractional crystallization trend in the An-Ab-Or pattern, they are resulted from plagioclase accumulation. Group (1) is mainly made of stromatic leucosomes with high $(\mathrm{La} / \mathrm{Yb})_{\mathrm{N}}$ and $(\mathrm{Dy} / \mathrm{Yb})_{\mathrm{N}}$ ratios, indicating garnet or amphibole as the residual phases. However, at the given $\mathrm{CaO}$ content, the first group has relatively lower $\mathrm{Sr}$ content and $\mathrm{Sr} / \mathrm{Y}$ ratio compared to the low- $\mathrm{Mg}^{\#}$ adaktic rocks, suggesting a plagioclase-rich source region instead of a garnet-rich, thickened lower crustal eclogitic source. Group (2), the diatexis leucosomes, is characterized by low $(\mathrm{La} / \mathrm{Yb})_{\mathrm{N}}$, $(\mathrm{Dy} / \mathrm{Yb})_{\mathrm{N}}$ and $\mathrm{Sr} / \mathrm{Y}$ ratios, which suggests no residual garnet or amphibole in the source during partial melting. In summary, the leucosomes are produced by middle crustal partial melting rather than thickened lower crustal melting.

\subsection{Partial melting conditions of migmatite}

Large and euhedral amphibole in leucosome indicates that it was crystallized from the melt rather than a residual mineral. 

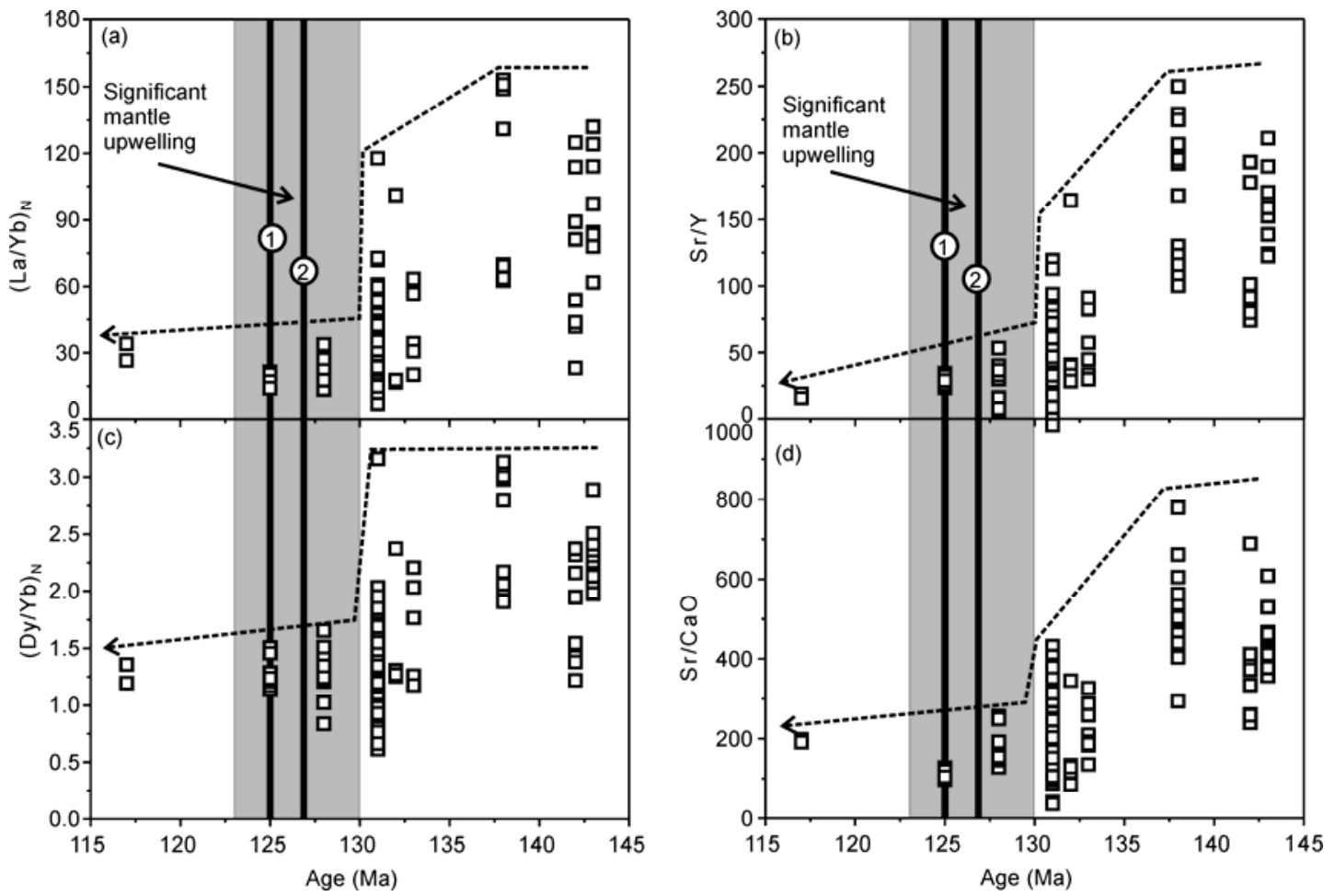

Figure 2 Disappearing of high $(\mathrm{La} / \mathrm{Yb})_{\mathrm{N}}, \mathrm{Sr} / \mathrm{Y},(\mathrm{Dy} / \mathrm{Yb})_{\mathrm{N}}$ and $\mathrm{Sr} / \mathrm{CaO}$ in Dabie post-collisional granites at ca. $130 \mathrm{Ma}$ [17]. The vertical lines 1, 2 and grey fields represent the ages and $2 \sigma$ range of Shacun $(125 \pm 2 \mathrm{Ma})$ and Jiaoziyan (127 $\pm 3 \mathrm{Ma}$ ) mafic plutons.

Considering that amphibole contains plagioclase + quartz inclusions, the melting reaction can be expressed as

$$
\mathrm{Bt}+\mathrm{Pl}+\mathrm{Qtz}+\text { fluid } \rightarrow \mathrm{Hbl}+\text { melt }[28,29]
$$

In such reaction, biotite and plagioclase are residual phases, while amphibole is the peritectic phase. The reactant mineral assemblage indicate a felsic gneiss as the source. Based on Hbl-Pl geothermometer [30] and Al-in-amphibole barometer [31], the calculated melting condition is 706$774^{\circ} \mathrm{C}$ at $0.5-0.7 \mathrm{GPa}$, corresponding to the depth of middle orogenic crust $(20-25 \mathrm{~km})$. Furthermore, leucosomes have low $\mathrm{Rb}$ and high $\mathrm{K} / \mathrm{Rb}$ compared to adakitic and normal granites. This may be caused by the residual biotites which have high $\mathrm{Rb}$ and low $\mathrm{K} / \mathrm{Rb}$. Biotite presented as a residue mineral during partial melting indicates that migmatites were formed by middle crustal rather than thickened LCC melting.

Recent geochronology studies show the North Dabie UHPM slices has been exhumed to middle crust at 191-200 $\mathrm{Ma}$, and has experienced amphibolite-faices retrograde metamorphism [32], corresponding to the metamorphic temperature of $400-500^{\circ} \mathrm{C}$. Therefore, partial melting of the exhumed UHPM rocks in the North Dabie zone at middle crust lavel in early Cretaceous also require a external heat source. Middle crustal migmatization and partial melting of thickened LCC producing adakitic rocks both could be the response to this heating event. Then, here comes the following questions: why did partial melting of the thickened crust occur prior to the mountain-root removal and mantle-upwelling, and where was the heat from?

\section{How did the middle-lower crust of the Dabie orogen get hot in the early Cretaceous?}

Taking the middle crust as an example, the early Cretaceous partial melting of the Dabie middle crust occurred at $700-800^{\circ} \mathrm{C}$, while the normal temperature of middle crust is generally $400-500^{\circ} \mathrm{C}$, suggesting a temperature increase of $300^{\circ} \mathrm{C}$ in the Dabie middle crust. Three possible processes contributed to the heat of middle crust could be proposed: (1) radiogenic heat production in a thickened crust; (2) heat conduction by intrusive magmas from deeper sources; and (3) lithospheric mantle thinning, which can increase the geothermal gradient in mantle lithosphere. As discussed below, the mechanism (3) is preferred, while the mechnisms (1) and (2) are unlikely.

\subsection{Radiogenic heat production of thickened crust is unlikely to cause early Cretaceous partial melting of Dabie middle crust}

Crustal temperature of collisional zones is generally elevated at the first $60 \mathrm{Ma}$ after the crustal thickening by radiogenic decay of $\mathrm{U}$, Th and $\mathrm{K}$; then crustal temperature would return to initial level because of losing heat by erosion [33]. Breakoff of the subducted slab occurred at $\sim 226 \mathrm{Ma}$ in the Dabie orogen, and then UHPM slices exhumed and crustal shortening would make a thickened crust at ca. 220-210 Ma. According to the modeling [33], a peak temperature should be reached at 160-150 Ma. However, no late Jurassic 
magmatism has been found in the Dabie orogen, suggesting a low radiogenic heat production $\left(<2.5 \mu \mathrm{W} / \mathrm{m}^{3}\right)$ [33]. The erosion rate of orogens is an important factor limiting the crustal temperature elevation. The erosion rate was large in the Dabie orogen, because the materials from the Dabie orogen, including a large volume of UHPM rocks and minerals, began to deposit in the Hefei basin in the early Jurassic, indicating UHPM rocks has been exposed to surface by erosion [34]. Therefore, erosion could make the middle crustal temperature return to a normal level $\left(400-500^{\circ} \mathrm{C}\right)$ at $140 \mathrm{Ma}$ in the orogen [33]. Consequently, radiogenic heat production can not be the heat source of partial melting of the middle and thickenend crust in the Dabie orogen.

\subsection{Adakitic magmatic intrusion as a heat source}

No mafic magmatism occurred before $130 \mathrm{Ma}$ in the Dabie orogen. Magmatic intrusions from deeper sources were only adakitic intermediate to felsic ones. They were emplaced not only in the North Dabie zone, but also in the North Huaiyang zone, the Central Dabie zone, and the South Dabie zone. However, except for the North Dabie zone, no migmatites occurred at the other zones. Therefore, it is unlikely to heat the country rocks resulting partial melting in the middle crust by the emplacement of adakitic rocks.

\subsection{Elevated temperature of thickened LCC by lithospheric mantle thinning}

Since the temperature elevation as high as $700-800^{\circ} \mathrm{C}$ in the Dabie middle crust cannot be caused by radiogenic heat production and adakitic intrusions, the possible heat source from the upper mantle should be evaluated. Crustal geothermal modeling reveals that given the crustal thickness increases from 35 to $70 \mathrm{~km}$ while keeping the mantle lithospheric thickness constant $(115 \mathrm{~km})$, the temperature at the bottom of thickened LCC (Moho) never exceed $800^{\circ} \mathrm{C}$ [33]. Therefore, the mantle lithosphere underneath the orogen must be thinning first, the temperature of thickened mafic LCC can only be elevated to $900-1000^{\circ} \mathrm{C}$, which led to the initial partial melting by mantle lithosphere thinning. This mantle lithosphere thinning should be caused by removal of lithospheric keel rather than extensional thinning, because lithosphere extension can not only make the mantle lithospheric thinning but also the crustal thinning, expectably without adakitic rocks derived from partial melting of thickened LCC.

\section{An estimation of the lithospheric thinning extent and two-stage model for mountain-root removal}

If partial melting of the Dabie thickened crust in the early
Cretaceous was introduced by conductive heat from the upper mantle, we could make estimation for the extent of lithospheric mantle thinning. Geothermal gradient of cratonic mantle lithosphere has been determined to be ca. $6.6^{\circ} \mathrm{C} / \mathrm{km}$ [35]. Because of the depletion of radiogenic heatproduction elements, the geothermal gradient in the mantle lithosphere is dominated by heat conduction from the asthenosphere. Given that the temperature of the bottom of mantle lithosphere is about $1300^{\circ} \mathrm{C}$ [35], the depth of the lithospheric mantle could be $\leqslant 45 \mathrm{~km}$, given partial melting temperature of thickened $\mathrm{LCC}$ is $1000^{\circ} \mathrm{C}$ [36]. If the thickened crustal thickness was $70 \mathrm{~km}$, the thinned whole lithosphere thickness should be $115 \mathrm{~km}$, similar to that of normal lithosphere. This means the mantle lithospheric keel beneath the Dabie orogen had been removed prior to the early Cretaceous. Because of the lack of mafic magmatism in the Dabie orogen in the early Cretaceous, the mantle lithospheric keel removal process could be reasonably described by asthenosphere convective removal model [2].

Based on the results and considerations mentioned above, a two-stage model can be proposed for the mountain root removal for the Dabie orogen. The South China Block and the North China Block kept convergent movement from the Triassic to the Jurassic, which led to thickening of the crust and lithospheric mantle in the Dabie collision zone (Figure 3(a)). The thickened mantle lithospheric keel dipped into the asthenospheric mantle. The temperature gradient between the cold lithospheric keel and surrounding hot asthenospheric mantle caused the upper mantle convection (Figure 3(b)). This mantle convection would cause instability of the lithospheric keel that finally to be removed by the mantle convection at $\sim 145 \mathrm{Ma}$ [2]. This mantle convection removal process could make the lithospheric mantle thinned to depth $\leqslant 45 \mathrm{~km}$ beneath the thickened orogen crust (Figure 3(c)). The uplift of the boundary between the lithospheric and the asthenospheric mantle elevated the geothermal gradient of mantle lithosphere and thus the temperature of lower to middle crust. This induced the initial partial melting and produced the low- $\mathrm{Mg}^{\#}$ adakitic magmatism from the thickened lower crust and migmatites in the middle crust (Figure 3(c)). Partial melting of the thickened LCC would not only weaken the strength but also increase the density of the LCC. This triggered the delamination and foundering of the thickened mafic LCC and mountain root removal, which caused the upper mantle upwelling and partial melting of the middle to lower crust that have not foundered and produced the post-collisional mafic magmas and normal granites (Figure 3(d)). The two-stage model for the Dabie mountain root removal may have more common implications for the processes and mechanism of lithospheric thinning. It suggests that the asthenospheric convecting removal and delamination of thickened LCC as two mechanisms of lithospheric thinning are related to causality. 


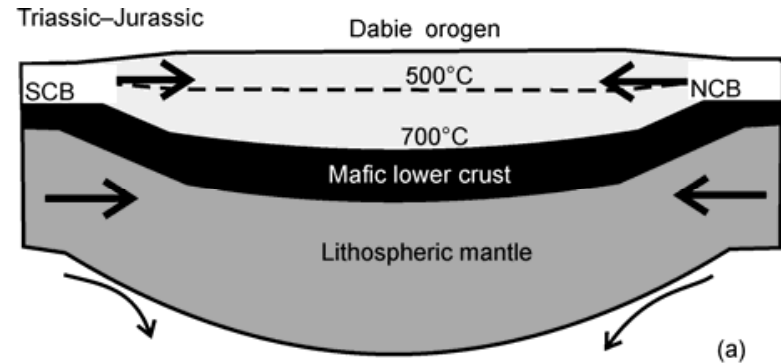

Jurassic-145 Ma
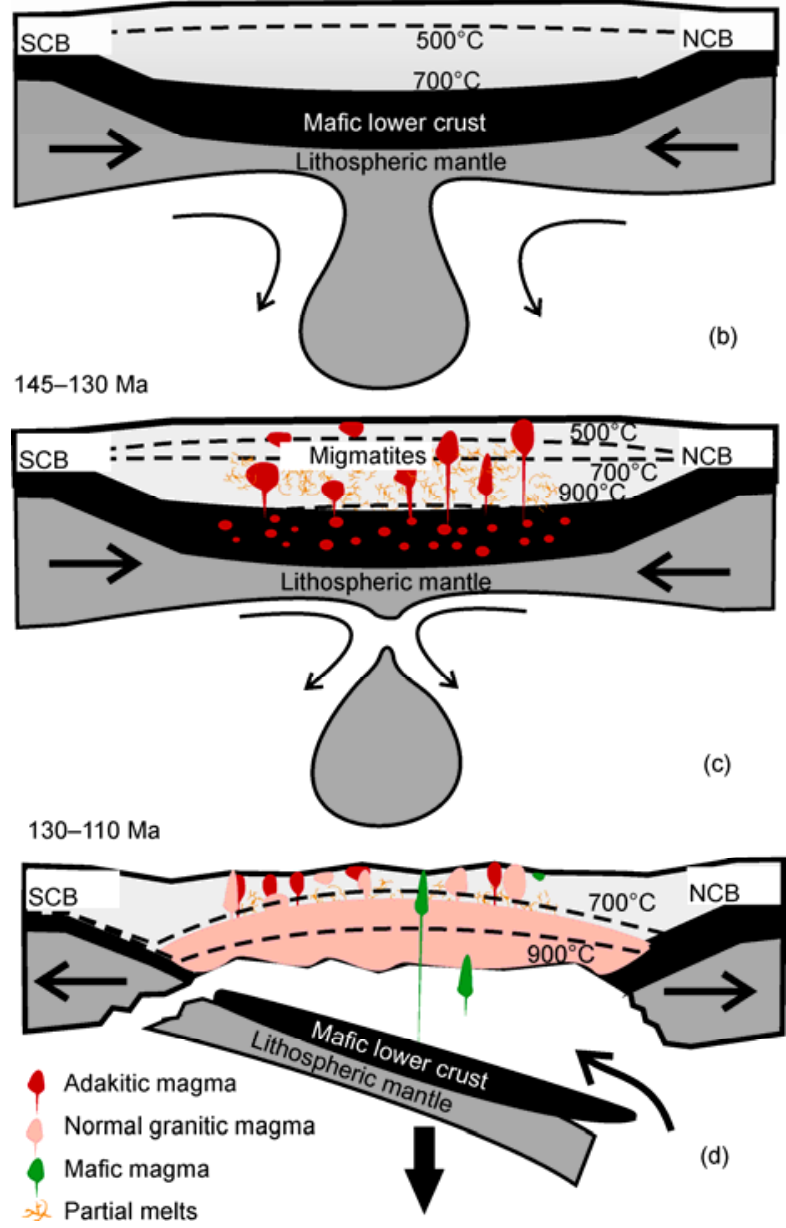

Figure 3 Two stage mountain root collapse model in the Dabie orgen.

This work was supported by the National Basic Research Program of China (2009CB825002) and the National Natural Science Foundation of China (40773013 and 91014007).

1 Gao S, Rudnick R L, Yuan H L, et al. Recycling lower continental crust in the North China craton. Nature, 2004, 432: 892-897

2 Molnar P, Houseman G A, Conrad C P. Rayleigh-Taylor instability and convective thinning of mechanically thickened lithosphere: Effects of non-linear viscosity decreasing exponentially with depth and of horizontal shortening of the layer. Geophys J Int, 1998, 133: $568-584$

3 Ma C Q, Yang K G, Ming H L, et al. The timing of tectonic transition from compression to extension in Dabieshan: Evidence from Mesozoic granites. Sci China Ser D-Earth Sci, 2004, 47: 453-462

4 Wang Q, Wyman D A, Xu J F, et al. Early Cretaceous adakitic granites in the Northern Dabie Complex, central China: Implications for partial melting and delamination of thickened lower crust. Geochim Cosmochim Acta, 2007, 71: 2609-2636

$5 \mathrm{Xu} \mathrm{H} \mathrm{J}$, Ma C Q, Ye K. Early cretaceous granitoids and their implications for the collapse of the Dabie orogen, eastern China: SHRIMP zircon U-Pb dating and geochemistry. Chem Geol, 2007, 240: $238-259$

6 Xu H J, Ma C Q, Song Y R, et al. Early Cretaceous intermediatemafic dykes in the Dabie orogen, eastern China: Petrogenesis and implications for crust-mantle interaction. Lithos, 2012, 154: 83-89

7 Macpherson C G, Dreher S T, Thirlwall M F. Adakites without slab melting: High pressure differentiation of island arc magma, Mindanao, the Philippines. Earth Planet Sci Lett, 2006, 243: 581-593

8 Richards J R, Kerrich R. Special paper: Adakite-like rocks: Their diverse origins and questionable role in metallogenesis. Economic Geol, 2007, 102: 537-576

9 Chen B, Jahn B M, Arakawa Y, et al. Petrogenesis of the Mesozoic intrusive complexes from the southern Taihang Orogen, North China Craton: Elemental and $\mathrm{Sr}-\mathrm{Nd}-\mathrm{Pb}$ isotopic constraints. Contrib Mineral Petrol, 2004, 148: 489-501

10 Guo F, Nakamuru E, Fan W M, et al. Generation of Palaeocene adakitic andesites by magma mixing; Yanji Area, NE China. J Petrol, 2007, 48: 661-692

11 Jiang N, Liu Y S, Zhou W G, et al. Derivation of Mesozoic adakitic magmas from ancient lower crust in the North China craton. Geochim Cosmochim Acta, 2007, 71: 2591-2608

12 Kamei A, Miyake Y, Owada M, et al. A pseudo adakite derived from partial melting of tonalitic to granodioritic crust, Kyushu, southwest Japan arc. Lithos, 2009, 112: 615-625

13 Moyen J F. High $\mathrm{Sr} / \mathrm{Y}$ and $\mathrm{La} / \mathrm{Yb}$ ratios: The meaning of the "adakitic signature". Lithos, 2009, 112: 556-574

14 Zhang S B, Zheng Y F, Zhao Z F, et al. Origin of TTG-like rocks from anatexis of ancient lower crust: Geochemical evidence from neoproterozoic granitoids in South China. Lithos, 2009, 113: 347368

15 Wang S J, Li S G, Chen L J, et al. Geochronology and geochemistry of leucosomes in the North Dabie Terrane, East China: Implication for post-UHPM crustal melting during exhumation. Contrib Mineral Petrol, 2013, 165: 1009-1029

16 Li J W, Zhao X F, Zhou M F, et al. Late Mesozoic magmatism from the Daye region, eastern China: U-Pb ages, petrogenesis, and geodynamic implications. Contrib Mineral Petrol, 2009, 157: 383-409

17 He Y S, Li S G, Hoefs J, et al. Post-collisional granitoids from the Dabie orogen: New evidence for partial melting of a thickened continental crust. Geochim Cosmochim Acta, 2011, 75: 3815-3838

18 He Y S, Li S G, Hoefs J, et al. Sr-Nd-Pb isotopic compositions of Early Cretaceous granitoids from the Dabie orogen: Constraints on the recycled lower continental crust. Lithos, 2013, 156-159: 204-217

19 Jahn B M, Wu F Y, Lo C H, et al. Crust-mantle interaction induced by deep subduction of the continental crust: Geochemical and $\mathrm{Sr}-\mathrm{Nd}$ isotopic evidence from post-collisional mafic-ultramafic intrusions of the northern Dabie complex, central China. Chem Geol, 1999, 157: $119-146$

20 Wang Y J, Fan W M, Peng T P, et al. Nature of the Mesozoic lithospheric mantle and tectonic decoupling beneath the Dabie Orogen, Central China: Evidence from Ar-40/Ar-39 geochronology, elemental and $\mathrm{Sr}-\mathrm{Nd}-\mathrm{Pb}$ isotopic compositions of early Cretaceous mafic igneous rocks. Chem Geol, 2005, 220: 165-189

21 Zhao Z F, Zheng Y F, Wei C S, et al. Zircon U-Pb age, element and $\mathrm{C}-\mathrm{O}$ isotope geochemistry of post-collisional mafic-ultramafic rocks from the Dabie orogen in east-central China. Lithos, 2005, 83: 1-28

22 Huang F, Li S G, Dong F, et al. Recycling of deeply subducted continental crust in the Dabie Mountains, central China. Lithos, 2007, 96: $151-169$

23 Zhao Z F, Zheng Y F, Wei C S, et al. Post-collisional granitoids from the Dabie orogen in China: Zircon U-Pb age, element and $\mathrm{O}$ isotope evidence for recycling of subducted continental crust. Lithos, 2007, 93: $248-272$

24 Hou Z H, Li S G, Chen N S, et al. Sm-Nd and zircon SHRIMP U-Pb dating of Huilanshan mafic granulite in the Dabie Mountains and its 
zircon trace element geochemistry. Sci China Ser D-Earth Sci, 2005, 48: 2081-2091

25 Wang G C, Yang W R. Spatial and temporal uplifting distribution of the Dabie orogen: Evidences from structure and geochronology. Earth Sci, 1998, 23: 461-467

26 Zhang H, Sun W D, Yang X Y, et al. Geochronology and metallogenesis of the Shapinggou giant porphyry molybdenum deposit in the Dabie orogenic Belt. Geol Acta, 2011, 85: 2039-2059

27 Wu Y B, Zheng Y F, Zhang S B, et al. Zircon U-Pb ages and $\mathrm{Hf}$ isotope compositions of migmatite from the North Dabie terrane in China: Constraints on partial melting. J Metamorphic Geol, 2007, 25: 991-1009

28 Cruciani G, Franceschelli M, Jung S, et al. Amphibole-bearing migmatites from the Variscan Belt of NE Sardinia, Italy: Partial melting of mid-Ordovician igneous sources. Lithos, 2008, 105: 208224

29 Slagstad T, Jamieson R, Culshaw N. Formation, crystallization, and migration of melt in the mid-orogenic crust: Muskoka domain migmatites, Grenville Province, Ontario. J Petrol, 2005, 46: 893-919

30 Holland T, Blundy J. Non-ideal interactions in calcic amphiboles and their bearing on amphibole-plagioclase thermometry. Contrib Mineral Petrol, 1994, 116: 433-447

31 Schmidt M. Amphibole composition in tonalite as a function of pressure: an experimental calibration of the Al-in-hornblende barometer. Contrib Mineral Petrol, 1992, 110: 304-310

32 Wang S J, Li S G, An S C, et al. A granulite record of multistage metamorphism and REE behavior in the Dabie orogen: Constraints from zircon and rock-forming minerals. Lithos. Lithos, 2012, 136-139: 109-125

33 Clark C, Fitzsimons I, Healy D, et al. How does the continental crust get really hot? Elements, 2011, 7: 235-240

34 Li R W, Wan Y S, Chen Z Y, et al. The Dabie orogen as the early Jurassic sedimentary provenance: Constraints from the detrital zircon SHRIMP U-Pb dating. Sci China Ser D-Earth Sci, 2004, 34: 320328

35 Hasterok D, Chapman D S. Heat production and geotherms for the continental lithosphere. Earth Planet Sci Lett, 2011, 307: 59-70

36 Rapp R, Watson E B, Miller C F. Partial melting of amphibolite/ eclogite and the origin of Archean trondhjemites and tonalities. Precambrian Res, 1991, 51: 1-25

Open Access This article is distributed under the terms of the Creative Commons Attribution License which permits any use, distribution, and reproduction in any medium, provided the original author(s) and source are credited. 